\title{
Influence of energy removal rate on the quality of minced meat from undersized crawfish during frozen storage
}

\author{
Franklin Bonilla ${ }^{1}$, Vondel Reyes ${ }^{1}$, Alexander Chouljenko ${ }^{1}$, Bennett Dzandu ${ }^{1}$ and Subramaniam Sathivel ${ }^{1,2^{*}}$
}

\begin{abstract}
Undersized crawfish have little economic value and are often discarded. Producing crawfish minced meat (CMM) from undersized crawfish and using an appropriate freezing technique may enable an economically viable market. The objective of this research was to evaluate the effect of the energy removal rate using two techniques, cryogenic freezing (CF) and air blast freezing (BF), on CMM's quality during frozen storage. CMM was separated into two batches; one batch was cryogenically frozen with liquid nitrogen and the other batch was frozen with an air blast freezer. CMM batches were frozen and stored at $-18^{\circ} \mathrm{C}$. They were analyzed for moisture content, color, $\mathrm{pH}$, and lipid oxidation during 180 days of storage. The CMM yield was $64.67 \%$ of the total crawfish weight. Cryogenic freezing achieved the highest freezing rate. Cryogenically frozen CMM showed 22\% less lipid oxidation than CMM frozen by air blast freezing at 180 days of storage. This study showed that CMM could be mechanically produced from undersized crawfish and freezing techniques with high energy removal rate could better maintain quality attributes for CMM during frozen storage.
\end{abstract}

Keywords: Crawfish, Minced meat, Cryogenic freezing, Air blast freezing

\section{Introduction}

The Southern U.S. is characterized for being the largest crustacean farming area in the nation, with average annual production of 30 to 50 million pounds. Crawfish aquaculture in Louisiana is controlled by Procambarus clarkii (red swamp) and P. zonangulus (white river); however, the $P$. clarkii is the desired specie in the marketplace and the preferred species for culture. Louisiana is the biggest state in crawfish production, with $90 \%$ of the total annual production located in the southern part of the state (McClain and Romaire 2004; Romaire et al. 2004).

\footnotetext{
* Correspondence: ssathivel@agcenter.Isu.edu

Approved for publication by the director of the Louisiana Agricultural Experimental Station as Manuscript number 2020-XXX-XXXX.

'School of Nutrition and Food Sciences, 220 Wilson Laboratories, Louisiana State University Agricultural Center, Baton Rouge, LA 70803, USA

${ }^{2}$ Department of Biological and Agricultural Engineering, Louisiana State University Agricultural Center, Baton Rouge, LA 70803, USA
}

The offer of crawfish is highly seasonal, with the peak of the season occurring from March to June. Smaller crawfish are usually processed for the tail meat market, and the larger crawfish are designated for the more profitable live market. Thousands of small crawfish are not harvested because they are not acceptable for either processing or commercialization. The smallest grades are by-products of the grading process or discarded by the processing plant. Approximately $20 \%$ of the total crawfish produced in recent years are underutilized. A potential solution could be a frozen crawfish minced meat (CMM) to utilize those undersized crawfish for processed meat through value added products and increased distribution (Harrison et al. 2002; Romaire et al. 2005). Fresh crawfish, due to its elevated moisture and nutrient contents, is a highly perishable seafood product. The primary preservation technique is using low temperatures to help reduce rates of microbiological and chemical changes. Several researches have studied meat quality

(c) The Author(s). 2020 Open Access This article is licensed under a Creative Commons Attribution 4.0 International License, which permits use, sharing, adaptation, distribution and reproduction in any medium or format, as long as you give appropriate credit to the original author(s) and the source, provide a link to the Creative Commons licence, and indicate if changes were made. The images or other third party material in this article are included in the article's Creative Commons licence, unless indicated otherwise in a credit line to the material. If material is not included in the article's Creative Commons licence and your intended use is not permitted by statutory regulation or exceeds the permitted use, you will need to obtain permission directly from the copyright holder. To view a copy of this licence, visit http://creativecommons.org/licenses/by/4.0/. 
variations during refrigerated or frozen conditions (Dorsa et al. 1993; Godber et al. 1989; Tseng et al. 2002).

Freezing is a food preservation technique that has been used for thousands of years due to long storage times at low temperatures extending product quality (Persson and Londahl 1993).

These quality attributes could vary through the freezing process, including pre-freezing and the postfreezing conditions during storage (George 1993; Persson and Londahl 1993). Freezing influences changes on food products by the freezing rate, the frozen storage conditions, and the thawing rate (Jasper and Placzek 1980). The main changes during frozen seafood storage are lipid oxidation (Subramanian 2007), color changes (Rahman and Velez-Ruiz 2004), denaturation of protein (Simpson 1997), sublimation and recrystallization of ice (Bhobe and Pai 1986). These can lead to off flavor, lipid oxidation, drip loss, dehydration, and toughening (Bhobe and Pai 1986; Londahl 1997). Several freezing techniques have been used in the food industry, including air blast freezing (BF), cryogenic freezing (CF), plate freezing, and immersion freezing. However, the most adaptable and popular methods are $\mathrm{BF}$ and $\mathrm{CF}$. One main difference between these two methods is related to freezing rate and its effect on product quality (Boonsumrej et al. 2007; Espinoza et al. 2013; Goswami 2010). Higher freezing rate is positively correlated with the number of ice crystals, producing small crystals that better retain the texture of some products. However, slow freezing is related with undesirable effects such as drip on thawing (Tung 2004). The aim of this study was to evaluate the effects of the energy removal rate on specific quality parameters of CMM during 6 months of frozen storage.

\section{Materials and methods}

\section{Production, freezing, and storage of crawfish minced} meat

Undersized, live, red swamp crawfish (Procambarus clarkii) kindly provided by Bocage Crawfish LLC (Crowley, LA), were stunned in ice, placed in boiling water for 5 min and cooled in ice slurry. Then meat and shells were mechanically separated by passing the whole crawfish through a belt drum deboner machine (Baader 693, Lübeck, Germany) at the Food Processing Pilot Plant, LSU AgCenter (Baton Rouge, LA). Schematic diagram for producing crawfish minced meat (CMM) is shown in Fig. 1. The resulting CMM was separated into two batches by packing the product into $946.35 \mathrm{~mL}$ capacity Ziploc bags (SC, Johnson, Racine, WI). One batch was frozen with liquid nitrogen in a pilot scale cabinet-type cryogenic freezer (Air Liquide, Houston, TX). Temperature was recorded by inserting a thermocouple into the center of the Ziploc bag with the CMM until the center of the product reached $-18.30 \pm 1.84{ }^{\circ} \mathrm{C}$ (temperature was recorded at $2 \mathrm{~s}$ intervals). The temperature inside of the cryogenic freezer cabinet using liquid nitrogen was $-115.80 \pm 1.13{ }^{\circ} \mathrm{C}$. The other batch was frozen in an air blast freezer (ABF) (Environmental Growth Chambers, Chagrin Falls, $\mathrm{OH}$ ) with a set point of $-18{ }^{\circ} \mathrm{C}$. Temperature was recorded by inserting a U12 probe temperature data logger (HOBO, Bourne, MA) into the center of the Ziploc bag with the CMM until the center of the product reached $-18.32 \pm 0.41{ }^{\circ} \mathrm{C}$ (temperature was recorded at $30 \mathrm{~s}$ intervals). The air flow rate $\left(9.01 \mathrm{~L} \mathrm{~s}^{-1}\right)$ was provided by the freezer manufacturer. Both frozen batches were packed into Ziploc bags and kept in an $\mathrm{ABF}$ at $-18^{\circ} \mathrm{C}$ during frozen storage. Moisture content, $\mathrm{pH}$, lipid oxidation, and color were evaluated at 1, 30, 90 and 180 days of storage. Samples were defrosted at $4{ }^{\circ} \mathrm{C}$ before measurements for the different storage times. A total of 12 samples per freezing technique were used in this study and three samples were analyzed at each evaluation time.

\section{Proximate and minerals composition of crawfish minced meat}

CMM was analyzed for moisture, protein, lipid, ash, and minerals content. Moisture content was determined according to AOAC (1995). Protein was analyzed using the Dumas method with a Leco TruSpec nitrogen

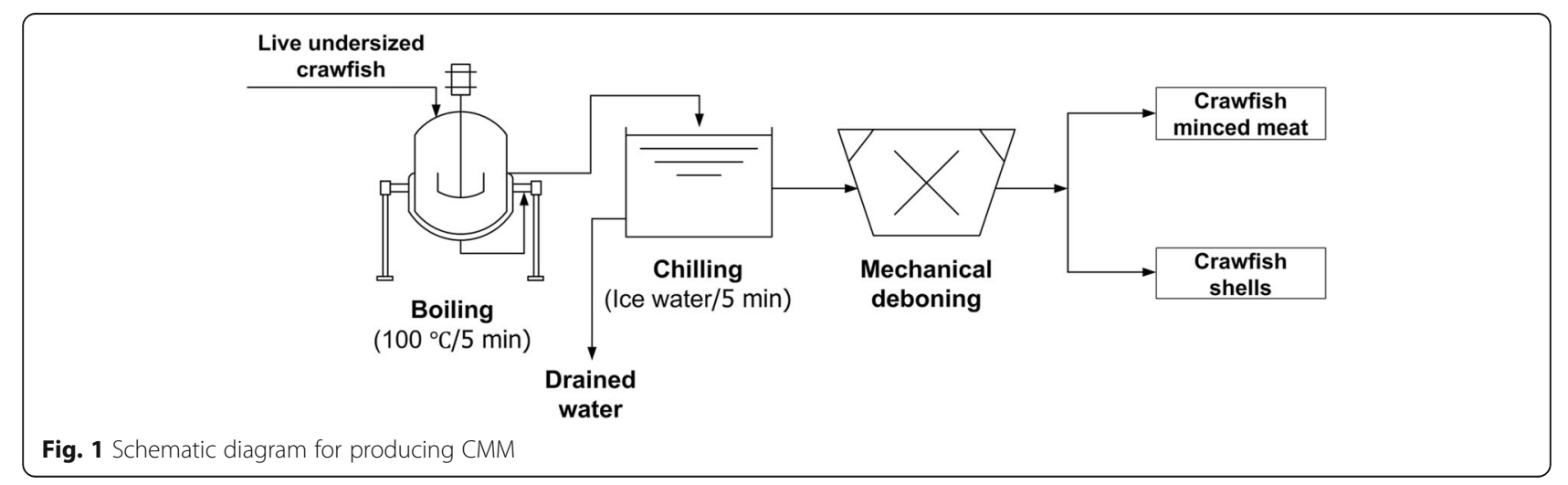


analyzer, using 6.25 as conversion factor for performing protein content calculations and the mineral analysis was performed using inductively coupled plasma (ICP) analysis (Baker and Amacher 1982; Barnhisel and Bertsch 1982; Mehlich 1984) at the Soil Testing and Plant Analysis Laboratory, LSU AgCenter. Lipid content was obtained by the Soxhlet extraction method AOAC 960.39 ( 1995), and ash was analyzed according to AOAC (1999).

\section{Crawfish minced meat's energy removal rate}

Measurement of energy removal rate (ERR) was done according to the methods of Espinoza et al. (2013). ERR of CMM was determined using the following equation:

$$
E R R=\Delta h / t
$$

where $E R R$ is the rate of heat transfer $\left(\mathrm{kJ} \mathrm{s}^{-1}\right), \Delta h$ is the product heat load $(\mathrm{kJ})$, and $t$ is the freezing time (FT) for the CMM (s). FT was calculated using the internal temperature recorded of CMM for the two freezing techniques.

$$
\Delta h=m\left[C_{p u}\left(T_{o}-T_{i f}\right)+L+C_{p f}\left(T_{i f}-T_{f}\right)\right]
$$

where $\Delta h$ is the CMM heat load $(\mathrm{kJ}) ; m$ is the weight of frozen CMM (kg); $C_{p u}$ is the specific heat capacity $(\mathrm{kJ}$ $\mathrm{kg}^{-1} \mathrm{~K}^{-1}$ ) of unfrozen CMM; $C_{p f}$ is the specific heat capacity $\left(\mathrm{kJ} \mathrm{kg}^{-1} \mathrm{~K}^{-1}\right)$ of frozen CMM; $T_{o}$ is the initial temperature of the $\mathrm{CMM}\left(5.6{ }^{\circ} \mathrm{C}\right.$ for $\mathrm{CF}$ and $5.89^{\circ} \mathrm{C}$ for $\mathrm{BF}) ; T_{i f}$ is the initial freezing temperature and $T_{f}$ is the final freezing temperature $\left(-18.40^{\circ} \mathrm{C}\right.$ for $\mathrm{CF}$ and $18.36^{\circ} \mathrm{C}$ for BF). The specific heat capacity $\left(C_{p u}\right.$ or $\left.C_{p f}\right)$ was calculated using Siebel (1982). Latent heat $(L)$ was calculated using Eq. (3).

$$
L=x_{i} L^{\prime}
$$

where $L$ ' is the latent heat of fusion of water $(333.6 \mathrm{~kJ}$ $\mathrm{kg}^{-1}$ ) and $x_{i}$ is the weight fraction of ice. $x_{i}$ was calculated using Eq. (4).

$$
x_{i}=\left(x_{w u}-B x_{s}\right)\left[\left(T_{i f}-T_{f}\right) /\left(T_{o}-T_{f}\right)\right]
$$

where $x_{w u}$ is the weight fraction of water, $x_{\mathrm{s}}$ is the weight fraction of solute, and $B$ is $\mathrm{kg}$ bound water per $\mathrm{kg}$ solute. Bound water was calculated using Eq. (5).

$$
B=b-0.5\left(M_{w} / M_{s}\right)
$$

where $M_{w}$ and $M_{s}$ are the molecular weight of water and solutes, respectively. $b$ is a constant $(b=0.1924)$ that was reported for fish species with similar composition to CMM by Pham (1987). The molecular weight of solutes was calculated using Eq. (6).

$$
M_{s}=18.02\left[\left(X_{w}\left(1-x_{w u}\right) /\left(x_{w u}\left(1-X_{w}\right)\right]\right.\right.
$$

where $X_{w}$ is the mole fraction of water of CMM. $X_{w}$ was calculated using Eq. (7).

$$
\ln \left(X_{w}\right)=-18.02\left[L^{\prime}\left(T_{o}-T_{i f}\right) /\left(R T_{o}^{2}\right)\right]
$$

where $R$ is the gas constant $\left(8.314 \mathrm{~kJ} \mathrm{kmol}^{-1} \mathrm{~K}^{-1}\right)$ and temperature unit is in Kelvin. Freezing rate $(\mathrm{FR})\left({ }^{\circ} \mathrm{C} \mathrm{min}^{-1}\right)$ was estimated using Eq. (8).

$$
\mathrm{FR}=\left(\mathrm{T}_{\mathrm{o}}-\mathrm{T}_{\mathrm{f}}\right) / \mathrm{t}
$$

where $t$ is the total FT (min). Three assumptions were defined for the above calculations: (1) water is the only constituent being frozen; (2) the internal temperature of CMM represents its average temperature; (3) all ice crystals are formed at the initial freezing temperature.

\section{Moisture content, $\mathrm{pH}$, thiobarbituric-acid-reactive- substances (TBARS), and color of crawfish minced meat} Moisture of CMM was determined according to AOAC (1995). The $\mathrm{pH}$ of CMM was obtained with the method described by Sundararajan et al. (2011). Thiobarbituricacid-reactive-substances (TBARS) analysis was used to determine lipid oxidation of CMM during frozen storage and was carried out according to Lemon (1975).

Color was measured using a colorimeter (Labscan XE, Hunter Associates Laboratory, Inc., Reston, VA) and reported as $L^{\prime \prime}, a^{\prime \prime}$ and $b^{\prime \prime}$ values. The total color difference $\left(\Delta \mathrm{E}^{\prime \prime}\right)$ between the fresh CMM and CMM at each of the different storage times was determined using Eq. (9). $\Delta$ $\mathrm{E}^{*}=\sqrt{\left(\Delta \mathrm{L}^{*}\right)^{2}+\left(\Delta \mathrm{a}^{*}\right)^{2}+\left(\Delta \mathrm{b}^{*}\right)^{2}}$ (9) where $\Delta L^{*}, \Delta a^{*}$, and $\Delta b^{*}$ were the changes in $L^{*}, a^{*}$, and $b^{*}$ values between the fresh and stored CMM.

\section{Statistical analysis}

Statistical Analysis Systems software (SAS, Version 9.2) was used to analyze the data obtained from triplicate samples for the two freezing techniques treatments. To determine differences among freezing techniques treatments, one-way and two-way Analysis of variance and Tukey's test were used at $P<0.05$. 


\section{Results and discussion}

Proximate analysis, minerals composition, and yield of crawfish minced meat

The proximate composition (\%) of fresh CMM was moisture $(86.09 \pm 0.16)$, protein $(9.30 \pm 0.08)$, fat $(2.29 \pm$ $0.06)$, and ash $(1.18 \pm 0.03)$. The moisture content was higher than the one reported by Sidwell (1981) and USDA (2018) for boiled crawfish tails. Suvanich et al. (2000) reported that channel catfish frame mince had a moisture content of $83.70 \%$, which is similar to that obtained for CMM. Asgharzadeh et al. (2010) found that washing fish minced muscle could increase its moisture content. In the present study, cooking the crawfish before mincing may have allowed for greater water binding and higher moisture content in the resulting CMM. Protein content in boiled crawfish tail meat reported by Sidwell (1981) and USDA (2018) was two times higher than CMM. Fat content was greater in CMM compared to boiled tail meat. The content from the cephalothorax, claws, and walking legs that was incorporated into the CMM might have increased the moisture and lipid content. Values of macro and microminerals present in CMM are shown in Table 1. Shellfish are characterized for $\mathrm{Ca}, \mathrm{Na}, \mathrm{K}, \mathrm{P}, \mathrm{Fe}, \mathrm{Zn}, \mathrm{Se}$, and $\mathrm{Cu}$ contents (Ibironke et al. 2018; Venugopal and Gopakumar 2017). USDA (2018) reported the minerals present in boiled crawfish tail meat. Some variations in the mineral values are noticed when compared with our values. Iron, calcium and manganese content were higher in CMM than in boiled crawfish tail meat. However, phosphorus and potassium values were highest in the tail meat. Mineral discrepancies could be explained due to the CMM method extracted the content from the whole crawfish. The variations in proximate analyses of shellfish species according to Venugopal and Gopakumar (2017) are influenced by spawning cycle, gametogenesis, feed, season, and habitats. Crawfish yields were affected by harvest season and harvest type (trap or seine), normally the first harvest season reported greater tail meat yields. Trap harvested ponds yields were almost two times to the seine harvested ponds (D'Abramo and Niquette 1991). The CMM extraction method showed a yield (\%) of $64.67 \pm 0.79$. This method to produce CMM for this study could be very advantageous to the crawfish industry due to the high yield compared to tail meat yield of 15\% (Ozayan: Market analysis of new mincedmeat products made from undersized crawfish, unpublished). CMM could be a potential ingredient for value added seafood products. The U.S. seafood industry processed around 18,358 Mg of fish products including fish sticks, fish nuggets, and seafood patties in 2000. U.S. imported approximately $6000 \mathrm{Mg}$ of mince-based seafood during this same year (Harrison et al. 2002; U.S. Department of Commerce, N. O. A. A., and Administration 2001).

\section{Freezing time, freezing rate, and energy removal rate for crawfish minced meat}

Freezing prolongs quality, and has been the most popular preservation technique for several food products. This preservation method changes the liquid physical state of water's product into ice, and the product reaches temperatures below the freezing point. (Rahman and Velez-Ruiz 2004). The freezing curves for CMM reported that freezing time was significantly different between the two freezing methods (Table 2). Cryogenic FT was approximately 44 times more rapid than the $\mathrm{BF}$ method to reach $-18^{\circ} \mathrm{C}$ (final freezing temperature of CMM). Freezing systems can be categorized due to the energy required in determined time (freezing rate; FR) to covert ice from the surface to the center of the product. FR is influenced by the food properties and the efficiency of heat transfer, indicated by the heat transfer coefficient $(h)$; $h$ values are lower for $\mathrm{BF}\left(17-26 \mathrm{~W}\left(\mathrm{~m}^{2} \mathrm{~K}\right)^{-1}\right)$ compared to CF (100-140 W ( $\left.\left.\mathrm{m}^{2} \mathrm{~K}\right)^{-1}\right)$ (George 1993).

CMM frozen by CF showed a sharper slope than CMM frozen by BF (Fig. 2). This steeper slope is explained by the greater $h$. It is due to direct contact of CMM with the liquid nitrogen gas, resulting in a high heat transfer rate (Awonorin 1989; Goswami 2010). FR and ERR of CF were higher than $\mathrm{BF}(P<0.05)$. The proportion of FR and removal energy for CF to BF was around 55:1 and 44:1, respectively. Low FR and energy removal for BF could be due to the cold air having a lower $h$, prolonging holding times to reach the final temperature. Accordingly, FT is greatest for BF, normally measured in hours, while FT for the same

Table 1 Mineral content of crawfish minced meat

\begin{tabular}{llll}
\hline Macrominerals & Concentration $\left({\left.\mathrm{mg} 100 \mathrm{~g}^{-1}\right)}^{\prime}\right.$ & Microminerals & Concentration $\left(\mathrm{mg}^{\left.100 \mathrm{~g}^{-1}\right)}\right.$ \\
\hline Calcium (Ca) & $72.67 \pm 6.76$ & Iron (Fe) & $9.88 \pm 0.36$ \\
Magnesium (Mg) & $17.05 \pm 0.25$ & Zinc ( $\mathrm{Zn})$ & $2.06 \pm 0.08$ \\
Potassium (K) & $161.08 \pm 5.81$ & Copper (Cu) & $0.91 \pm 0.04$ \\
Phosphorus (P) & $91.00 \pm 2.48$ & Manganese (Mn) & $2.81 \pm 0.13$ \\
Sodium (Na) & $126.27 \pm 4.62$ & & \\
Sulphur (S) & $76.20 \pm 1.87$ & & \\
\hline
\end{tabular}


Table 2 Freezing time, freezing rate, and energy removal of crawfish minced meat

\begin{tabular}{llll}
\hline Freezing method & Freezing time $(\mathrm{min})$ & Freezing rate $\left({ }^{\circ} \mathrm{C} \mathrm{min}^{-1}\right)$ & Energy removal $\left(\mathrm{J} \mathrm{s}^{-1}\right)$ \\
\hline $\mathrm{CF}$ & $4.40 \pm 0.33^{\mathrm{b}}$ & $5.47 \pm 0.41^{\mathrm{a}}$ & $1005.86 \pm 75.43^{\mathrm{a}}$ \\
$\mathrm{BF}$ & $192.37 \pm 12.37^{\mathrm{a}}$ & $0.13 \pm 0.01^{\mathrm{b}}$ & $22.87 \pm 1.47^{\mathrm{b}}$ \\
\hline
\end{tabular}

${ }^{a-b}$ Means $\pm S D$ that have no superscript in common within a column are significantly different from each other $(P<0.05)$. $C F$ cryogenic freezing and $B F$ air blast freezing

products by CF are reported in minutes (Espinoza et al. 2013; George 1993).

Ice crystal size is indirectly proportional with the amount of nuclei formed. At high FR's, a substantial amount of nuclei are produced and the ice is dispersed in several tiny crystals. However, at low FR's, minor nuclei are produced, resulting in large crystal sizes (Sun 2016). Rapid freezing rates help produce small ice crystals, reducing the amount of drip loss substantially and improving quality retention of the product compared to freezing methods with slow FR's (Goswami 2010; Lakshmisha et al. 2008; Songsaeng et al. 2010).

\section{Moisture content and $\mathrm{pH}$ of crawfish minced meat during} frozen storage

Moisture content (g $100 \mathrm{~g}^{-1}$ ) of CMM at day 1 of storage at $-18{ }^{\circ} \mathrm{C}$ was $86.29 \pm 0.16$ for minced crawfish blast frozen $(\mathrm{MCBF})$ and $85.57 \pm 0.30$ for minced crawfish cryogenic frozen (MCCF) (Table 3). Within each respective treatment, the moisture content did not change from 1 to 180 days of storage. This suggests that both freezing techniques were adequate for retaining moisture in the minced meat during frozen storage. When comparing between both treatments, their moisture contents were similar from 90 to 180 days of storage. Similarly, Espinoza et al. (2013) found no differences between the moisture contents of air blast frozen and cryogenic frozen fish during 180 days at $-20 \pm 1{ }^{\circ} \mathrm{C}$.

The $\mathrm{pH}$ of $\mathrm{CMM}$ at day 1 of storage at $-18^{\circ} \mathrm{C}$ was $7.75 \pm 0.02$ for MCBF and $7.79 \pm 0.03$ for MCCF (Table 3). Within respective treatments, the $\mathrm{pH}$ did not change from 1 to 180 days of storage. Asgharzadeh et al. (2010) found that the $\mathrm{pH}$ of silver carp mince stored for 180 days at $-18^{\circ} \mathrm{C}$ did not change. The $\mathrm{pH}$ of fish may be used alongside other quality assessments as a tool to determine fish quality (RuizCapillas and Moral 2001). A decrease in $\mathrm{pH}$ during the stages of early storage can be from lactic acid formation. Longer storage can increase the $\mathrm{pH}$ due to decomposition of dimethylamine from trimethylamine oxide and other products (Rodger et al. 1980). Endogenous enzymes found in some seafood can develop decomposition products, leading to degradation during frozen storage (Fellows 2009). The cooking process for crawfish may help to inactivate proteolytic enzymes such as those found in the hepatopancreas of crawfish (Marshall et al. 1987). Like with fish, a stable CMM $\mathrm{pH}$ during frozen storage could reflect retention of quality. The initial post mortem $\mathrm{pH}$ of fish typically differs from 5.4 to 7.2 (Grigorakis et al. 2003). However, a different seafood matrix, CMM, had a $\mathrm{pH}$ above those values. This may be partially

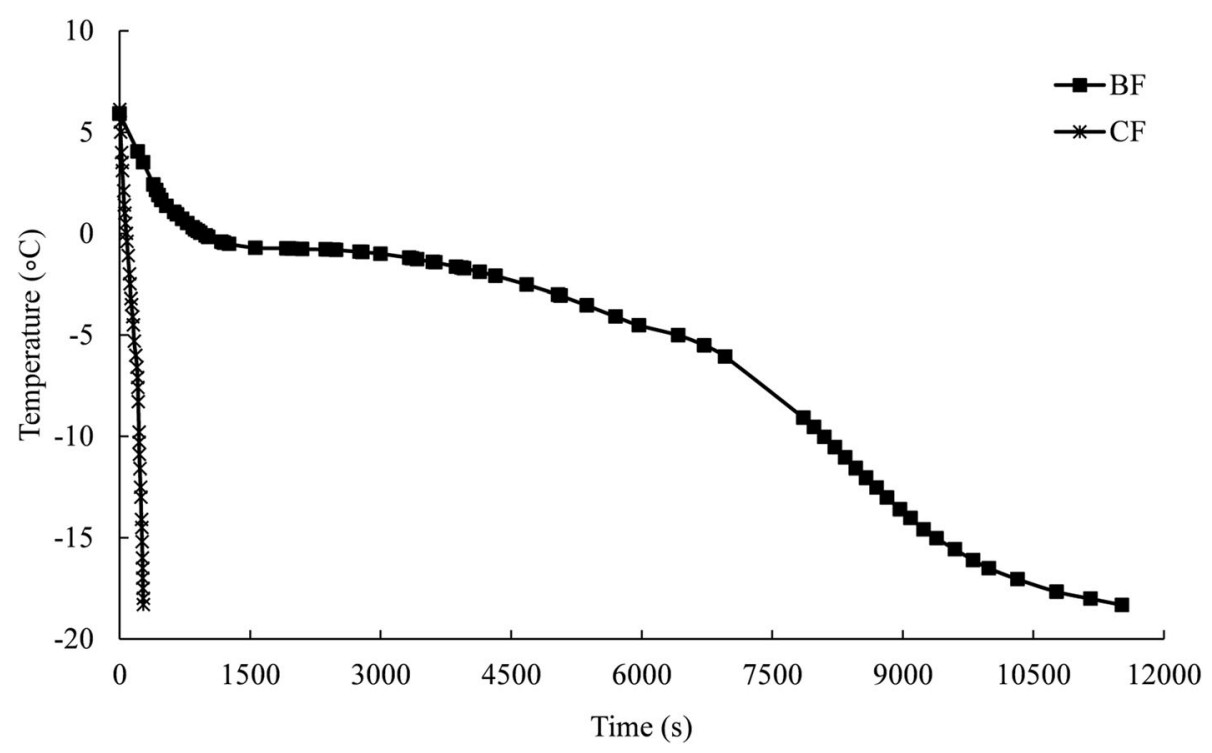

Fig. 2 Freezing curves of crawfish minced meat. $C F=$ cryogenic freezing and $B F=$ air blast freezing 
Table 3 Moisture content, $\mathrm{pH}$ and TBARS of crawfish minced meat during frozen storage

\begin{tabular}{|c|c|c|c|c|c|}
\hline & \multirow[t]{2}{*}{ Treatment } & \multicolumn{4}{|l|}{ Time (day) } \\
\hline & & 1 & 30 & 90 & 180 \\
\hline \multirow[t]{4}{*}{ Moisture $\left({\left.\mathrm{g} 100 \mathrm{~g}^{-1}\right)}\right.$} & MCCF & $85.57 \pm 0.30^{\mathrm{bA}}$ & $85.93 \pm 0.04^{\mathrm{aA}}$ & $84.45 \pm 0.51^{\mathrm{aB}}$ & $86.10 \pm 0.55^{\mathrm{aA}}$ \\
\hline & MCBF & $86.29 \pm 0.16^{\mathrm{aA}}$ & $84.36 \pm 0.50^{\mathrm{bB}}$ & $84.92 \pm 1.00^{\mathrm{aAB}}$ & $85.23 \pm 0.26^{\mathrm{aAB}}$ \\
\hline & MCCF & $7.79 \pm 0.03^{\mathrm{aA}}$ & $7.75 \pm 0.02^{\mathrm{aA}}$ & $7.69 \pm 0.02^{\mathrm{aB}}$ & $7.74 \pm 0.01^{\mathrm{aAB}}$ \\
\hline & MCBF & $7.75 \pm 0.02^{\mathrm{aA}}$ & $7.71 \pm 0.04^{\mathrm{aAB}}$ & $7.66 \pm 0.01^{\mathrm{bB}}$ & $7.70 \pm 0.01^{\mathrm{bAB}}$ \\
\hline \multirow[t]{2}{*}{ TBARS (mg MDA equiv. $\mathrm{Kg}^{-1}$ ) } & MCCF & $0.31 \pm 0.01^{a c}$ & $0.33 \pm 0.01^{a c}$ & $0.71 \pm 0.11^{\mathrm{aB}}$ & $1.01 \pm 0.09^{\mathrm{bA}}$ \\
\hline & MCBF & $0.32 \pm 0.02^{\mathrm{aC}}$ & $0.35 \pm 0.03^{\mathrm{aC}}$ & $0.60 \pm 0.08^{\mathrm{aB}}$ & $1.29 \pm 0.05^{\mathrm{aA}}$ \\
\hline
\end{tabular}

${ }^{a-b}$ Means \pm SD that have no superscript in common within a column are significantly different from each other $(P<0.05) .{ }^{A-C}$ Means $\pm S D$ that have no superscript in common within a row are significantly different from each other $(P<0.05)$. MCCF minced crawfish cryogenic frozen and $M C B F=$ minced crawfish blast frozen. MDA malondialdehyde, and TBARS thiobarbituric-acid-reactive-substances

due to the slightly alkaline $\mathrm{pH}(7.40 \pm 0.03)$ of the water used for cooking and cooling the crawfish.

\section{Lipid oxidation of crawfish minced meat during frozen storage}

In seafood frozen storage, the most common type of lipid oxidation is autoxidation, including a reduced enzymatically derived oxidation (Schultz 1962). At 1 day of storage, the thiobarbituric-acid-reactive-substances (TBARS) content of MCCF $\left(0.31 \pm 0.01 \mathrm{mg}\right.$ MDA equiv. $\left.\mathrm{kg}^{-1}\right)$ and $\operatorname{MCBF}\left(0.32 \pm 0.02 \mathrm{mg}\right.$ MDA equiv. $\left.\mathrm{kg}^{-1}\right)$ did not show significant difference (Table 3). Both treatments reported an increase of TBARS content from 30 to 180 days at $18^{\circ} \mathrm{C}(P<0.05)$. MCCF showed at the end of storage lower TBARS content than for MCBF. The CF method reduced approximately $22 \%$ of TBARS content compared to BF during 6 months at $-18^{\circ} \mathrm{C}$. Equivalent results were observed in whole crawfish, catfish fillets, and Indian mackerel during frozen storage where freezing methods with high ERR and short FT reduced lipid oxidation (Espinoza et al. 2013; Godber et al. 1989; Lakshmisha et al. 2008). The consequence of slow freezing methods on lipid oxidation of CMM could be lead due to differing amounts of damage caused to membrane lipids, which could be reflected through decrease of phospholipids that could interact with enzymes and substrates, thus increasing oxidation in frozen seafood products (Awad et al. 1968; Wanous et al. 1989).

\section{Color of crawfish minced meat during frozen storage}

The first food quality parameter judged by a customer is its visual perception. Appearance analyses are used on food quality evaluation through processing and after processing (Doughikollaee 2012; Sáenz et al. 1993). Initial $L^{*}$ values for MCCF reported higher lightness than for MCBF (Table 4). This may be explained due to the high FR's which normally lead to pale colors due to the small ice crystals that generate scattering of incident light (Sun 2016). $L^{* \prime}$ values for CMM treatments showed a significant decrease through the storage times. Nevertheless, after 6 months of storage there were not significant differences between treatments. Additionally, color changes and particular modifications of lightness could be the outcome of protein denaturation (Doughikollaee 2012). Slight changes occurred in $a^{*}$ and $b^{*}$ values for the different $C M M$ treatments during frozen storage. Fresh CMM color $\left(L^{\prime \prime}=47.2 \pm 0.64, a^{* \prime}=15.42 \pm 0.19\right.$, and $\left.b^{*}=20.45 \pm 0.39\right)$ was used to get the total color difference $\left(\Delta E^{\prime \prime}\right)$ for the different storage times. Marshall et al. (1988) reported similar values for freshly processed meat

Table 4 Color of crawfish minced meat during frozen storage

\begin{tabular}{|c|c|c|c|c|c|}
\hline & \multirow[t]{2}{*}{ Treatment } & \multicolumn{4}{|l|}{ Time (day) } \\
\hline & & 1 & 30 & 90 & 180 \\
\hline \multirow[t]{2}{*}{$\overline{L^{*}}$} & MCCF & $51.29 \pm 0.73^{\mathrm{aA}}$ & $48.20 \pm 1.52^{\mathrm{aB}}$ & $46.08 \pm 0.52^{\mathrm{aB}}$ & $46.69 \pm 1.39^{\mathrm{aB}}$ \\
\hline & MCBF & $48.72 \pm 0.15^{\mathrm{bA}}$ & $48.07 \pm 0.67^{\mathrm{AA}}$ & $43.38 \pm 0.57^{b c}$ & $46.79 \pm 0.22^{\mathrm{aB}}$ \\
\hline \multirow[t]{2}{*}{$a^{*}$} & MCCF & $15.61 \pm 0.27^{\mathrm{bC}}$ & $18.32 \pm 0.61^{\mathrm{bB}}$ & $18.38 \pm 1.00^{\mathrm{aB}}$ & $20.46 \pm 0.54^{\mathrm{aA}}$ \\
\hline & MCBF & $17.40 \pm 0.66^{\mathrm{aB}}$ & $20.60 \pm 0.66^{\mathrm{aA}}$ & $19.48 \pm 0.90^{\mathrm{aA}}$ & $18.70 \pm 0.79^{\mathrm{bAB}}$ \\
\hline \multirow[t]{2}{*}{$b^{*}$} & MCCF & $21.91 \pm 0.30^{\mathrm{bB}}$ & $23.47 \pm 0.32^{\mathrm{bAB}}$ & $24.40 \pm 1.06^{\mathrm{aA}}$ & $24.47 \pm 0.91^{\mathrm{aA}}$ \\
\hline & MCBF & $24.56 \pm 1.10^{\mathrm{aAB}}$ & $26.27 \pm 1.04^{\mathrm{aA}}$ & $23.84 \pm 0.56^{\mathrm{aAB}}$ & $22.78 \pm 1.27^{\mathrm{aB}}$ \\
\hline \multirow[t]{2}{*}{$\Delta E^{*}$} & MCCF & $4.34 \pm 0.80^{\mathrm{aA}}$ & $4.50 \pm 0.28^{\mathrm{bA}}$ & $5.08 \pm 1.44^{\mathrm{aA}}$ & $6.59 \pm 0.78^{\mathrm{aA}}$ \\
\hline & MCBF & $4.81 \pm 1.25^{\mathrm{aAB}}$ & $7.85 \pm 1.25^{\mathrm{aA}}$ & $6.56 \pm 0.96^{\mathrm{aAB}}$ & $4.10 \pm 1.26^{\mathrm{bB}}$ \\
\hline
\end{tabular}

${ }^{\mathrm{a}-\mathrm{b}}$ Means \pm SD that have no superscript in common within a column are significantly different from each other $(P<0.05)$. ${ }^{\mathrm{A}-\mathrm{C}}$ Means \pm SD that have no superscript in common within a row are significantly different from each other $(P<0.05)$. MCCF minced crawfish cryogenic frozen and $M C B F$ minced crawfish blast frozen 
of red swamp crawfish, but b*values of fresh CMM were higher than freshly processed meat. CMM's reddish color may be explained by addition of the pigment astaxanthin from the crawfish carapace through the method of extraction that employs pressure from belt to crawfish. There is no clear trend of color difference for the different treatments. MCBF total color difference showed significant difference at 1 day and 180 days of frozen storage. However, MCCF reported similar total color difference through frozen storage $(\mathrm{P}<0.05)$. Freezing method could have an effect on $\Delta \mathrm{E}^{\prime \prime}$ during storage, as similar results were reported by Espinoza et al. (2013).

\section{Conclusion}

The rapid freezing method extended quality parameters of crawfish minced meat during frozen storage. Cryogenic freezing reduced lipid oxidation of crawfish minced meat by $22 \%$ compared to the slow freezing method (air blast freezing), and showed significant benefits such as high freezing rates and shorter freezing times. Color difference stability was reported for cryogenically frozen crawfish minced meat. Cryogenic freezing was superior to air blast freezing in yielding a frozen crawfish minced meat that could better withstand quality degradation during frozen storage. This research provides valuable information regarding the impact of processing and storage on the quality of a potentially marketable commodity obtained from undersized and underutilized crawfish.

\section{Abbreviations \\ ABF: Air blast freezer; BF: Air blast freezing; CCM: Crawfish minced meat; CF: Cryogenic freezing; ERR: Energy removal rate; FR: Freezing rate; FT: Freezing time; $h$ : heat transfer coefficient; MCBF: Minced crawfish blast frozen; MCCF: Minced crawfish cryogenic frozen; MDA: Malondialdehyde; TBARS: Thiobarbituric-acid-reactive-substances}

\section{Acknowledgements}

Not applicable.

\section{Authors' contributions}

SS and FB designed the study. FB, VR and BD performed and obtained the data. FB and AC analyzed and interpreted the results. SS, FB, and AC wrote the article. All authors read and approved the final manuscript.

\section{Funding}

This research did not receive any specific grant from funding agencies in the public, commercial, or not-for-profit sectors.

\section{Availability of data and materials}

All data generated or analyzed during this study are included in this published article. Further details are available from the corresponding author on reasonable request.

\section{Competing interests}

Declarations of interest: none.
Received: 24 May 2020 Accepted: 29 July 2020

Published online: 17 September 2020

\section{References}

AOAC (1995). Official methods of analysis, (17th ed., ). Gaithersburg: AOAC International.

AOAC (1999). Official methods of analysis of the Association of Official Analytical Chemists. Arlington: Association of Official Analytical Chemists.

Asgharzadeh, A., Shabanpour, B., Aubourg, S. P., \& Hosseini, H. (2010). Chemical changes in silver carp (Hypophthalmichthys molitrix) minced muscle during frozen storage: Effect of a previous washing process. Grasas y Aceites, 61(1), 95-101 https://doi.org/10.3989/gya.087109.

Awad, A., Powriep, W. D., \& Fennema, O. (1968). Chemical deterioration of frozen bovine muscle at $-4^{\circ} \mathrm{C}$. Journal of Food Science, 33(3), 227-235 https://doi. org/10.1111/j.1365-2621.1968.tb01355.x.

Awonorin, S. O. (1989). A model for heat transfer in cryogenic food freezing. International Journal of Food Science \& Technology, 24(3), 243-259 https://doi. org/10.1111/j.1365-2621.1989.tb00642.x.

Baker, D. E., \& Amacher, M. C. (1982). Nickel, copper, zinc, and cadmium 1. In Methods of soil analysis. Part 2. Chemical and microbiological properties, (pp. 323-336).

Barnhisel, R., \& Bertsch, P. M. (1982). Aluminum. In Methods of soil analysis. Part 2. Chemical and microbiological properties, (pp. 275-300).

Bhobe, A., \& Pai, J. (1986). Study of the properties of frozen shrimps. Journal of Food Science and Technology, 23(3), 143-147.

Boonsumrej, S., Chaiwanichsiri, S., Tantratian, S., Suzuki, T., \& Takai, R. (2007). Effects of freezing and thawing on the quality changes of tiger shrimp (Penaeus monodon) frozen by air-blast and cryogenic freezing. Journal of Food Engineering, 80(1), 292-299 https://doi.org/10.1016/j.jfoodeng.2006.04. 059.

D'Abramo, L. R., \& Niquette, D. J. (1991). Seine harvesting and feeding of formulated feeds as new management practices for pond culture of red swamp crawfish, Procambarus clarkii, and white river crawfish, P. acutus acutus. Journal of Shellfish Research, 10, 169-177.

Dorsa, W. J., Marshall, D. L., Moody, M. W., \& Hackney, C. R. (1993). Low temperature growth and thermal inactivation of Listeria monocytogenes in precooked crawfish tail meat. Journal of Food Protection, 56(2), 106-109 https://doi.org/10.4315/0362-028x-56.2.106.

Doughikollaee, E. A. (2012). Freezing / Thawing and Cooking of Fish, Scientific, Health and Social Aspects of the Food Industry, Dr. Benjamin Valdez (Ed.), ISBN: 978-953-307-916-5, InTech, Available from: http://www.intechopen.com/ books/scientific-health-and-social-aspects-of-the-food-industry/freezingthawingand-cookingof-fish

Espinoza, L. A., Sundararajan, S., Solval, K. M., Chotiko, A., Li, J., Zhang, J., ... Sathivel, S. (2013). Cryogenic and air blast freezing techniques and their effect on the quality of catfish fillets. LWT - Food Science and Technology, 54(2), 377-382 https://doi.org/10.1016/j.lwt.2013.07.005.

Fellows, P. J. (2009). Food processing technology: Principles and practice. El sevier.

George, R. M. (1993). Freezing proceseses used in the food industry. Trends in Food Science \& Technology, 4(5), 134-138. https://doi.org/10.1016/09242244(93)90032-6

Godber, J. S., Wang, J., Cole, M. T., \& Marshall, G. A. (1989). Textural attributes of mechanically and cryogenically frozen whole crayfish (Procambarus clarkii). Journal of Food Science, 54(3), 564-566 https://doi.org/10.1111/j.1365-2621. 1989.tb04652.x.

Goswami, T. K. (2010). Role of cryogenics in food processing and preservation. International Journal of Food Engineering, 6(1) https://doi.org/10.2202/15563758.1771 .

Grigorakis, K., Taylor, K., \& Alexis, M. (2003). Seasonal patterns of spoilage of icestored cultured gilthead sea bream (Sparus aurata). Food Chemistry, 81(2), 263-268 https://doi.org/10.1016/S0308-8146(02)00421-1.

Harrison, R. W., Stringer, T., \& Prinyawiwatkul, W. (2002). An analysis of consumer preferences for value-added seafood products derived from crawfish. Agricultural and Resource Economics Review, 31(2), 157-170 https://doi.org/10. 1017/S106828050000397X.

Ibironke, S. I., Adepeju, A. B., Otutu, O., Oyedele, D. S., \& Esan, Y. O. (2018). Nutritional evaluation and comparison study of seafoods such as fish and crayfish supplement dietary. MOJ Food Processing \& Technology, 1(6), 75-78.

Jasper, W., \& Placzek, R. (1980). Conservación de la carne por el frío (No. 637.551 JASC). 
Lakshmisha, I., Ravishankar, C., Ninan, G., Mohan, C. O., \& Gopal, T. (2008). Effect of freezing time on the quality of Indian mackerel (Rastrelliger kanagurta) during frozen storage. Journal of Food Science, 73(7), S345-S353 https://doi.org/10. 1111/j.1750-3841.2008.00876.x

Lemon, D. (1975). An improved TBA test for rancidity. New series circular no. 51. Environment Canada. Halifax: Fisheries and Marine Service.

Londahl, G. (1997). Technological aspects of freezing and glazing shrimp. Infofish International, 3, 49-56.

Marshall, G. A., Moody, M. W., \& Hackney, C. R. (1988). Differences in color, texture, and flavor of processed meat from red swamp crawfish (Procambarus clarkii) and white river crawfish (P. acutus acutus). Journal of Food Science, 53(1), 280-281 https://doi.org/10.1111/j.1365-2621.1988.tb10230.x.

Marshall, G. A., Moody, M. W., Hackney, C. R., \& Godber, J. S. (1987). Effect of blanch time on the development of mushiness in ice-stored crawfish meat packed with adhering hepatopancreas. Journal of Food Science, 52(6), 1504 1505 https://doi.org/10.1111/j.1365-2621.1987.tb05864.x

McClain, W. R., \& Romaire, R. P. (2004). Crawfish culture: A Louisiana aquaculture success story. World Aquaculture, 35(4), 31-35.

Mehlich, A. (1984). Mehlich-3 soil test extractant: A modification of Mehlich-2 extractant. Communications in Soil Science and Plant Analysis, 15(12), 1409$1416 \mathrm{https}: / /$ doi.org/10.1080/00103628409367568.

Persson, P., \& Londahl, G. (1993). Freezing technology. Frozen Food Technology, 20-58, First edition, (Chapter 2), Published by Brackle Academic \& Professional, Printed in England at the University Press, Cambridge. ISSBN 07514-0072-6, USA 0-442-30867-1

Pham, Q. T. (1987). Calculation of bound water in frozen food. Journal of Food Science, 52(1), 210-212 https://doi.org/10.1111/j.1365-2621.1987.tb14006.x.

Rahman, M. S., \& Velez-Ruiz, J. F. (2004). Food preservation by freezing. Food science and Technology-New York-Marcel Dekker, (Chapter 26).

Rodger, G., Weddle, R., \& Craig, P. (1980). Effect of time, temperature, raw material type, processing and use of cryoprotective agents on mince quality. In J. J. Connell (Ed.), Advances in fish science and technology. London: Fishing News Books Ltd.

Romaire, R. P., McClain, W. R., \& Lutz, C. G. (2004). Crawfish production: Harvesting. Southern Regional Aquaculture Center 2400, 1-4.

Romaire, R. P., McClain, W. R., Shirley, M. G., \& Lutz, C. G. (2005). Crawfish aquaculture-marketing. Southern Regional Aquaculture Center, 2402, 1-4.

Ruiz-Capillas, C., \& Moral, A. (2001). Correlation between biochemical and sensory quality indices in hake stored in ice. Food Research International, 34(5), 441447. https://doi.org/10.1016/S0963-9969(00)00189-7

Sáenz, C., Sepúlveda, E., Araya, E., \& Calvo, C. (1993). Colour changes in concentrated juices of prickly pear (Opuntia ficus indica) during storage at different temperatures. LWT-Food Science and Technology, 26(5), 417-421 https://doi.org/10.1006/fstl.1993.1082.

Schultz, H. W. (1962). Symposium on foods: Lipids and their oxidation. Paper presented at the symposium on foods: Lipids and their oxidation (1961: Oregon State University).

Sidwell, V. D. (1981). Chemical and nutritional composition of finfishes, whales, crustaceans, mollusks, and their products.

Siebel, J. E. (1982). Siebel equations for calculations of specific heat capacity (R. P. Singh \& D. R. Helmman, Eds.). Academic Press (2001).

Simpson, B. K. (1997). Innovation strategies for controlling fresh fish texture degradation during postharvest handling and storage, (pp. 161-177). Switzerland: Seafood safety processing and biotechnology. Technomic.

Songsaeng, S., Sophanodora, P., Kaewsrithong, J., \& Ohshima, T. (2010). Quality changes in oyster (Crassostrea belcheri) during frozen storage as affected by freezing and antioxidant. Food Chemistry, 123(2), 286-290 https://doi.org/10. 1016/j.foodchem.2010.04.033.

Subramanian, T. A. (2007). Effect of processing on bacterial population of cuttle fish and crab and determination of bacterial spoilage and rancidity developing on frozen storage. Journal of Food Processing and Preservation, 31(1), 13-31 https://doi.org/10.1111/j.1745-4549.2007.00101.x.

Sun, D.-W. (2016). Handbook of frozen food processing and packaging. CRC Press.

Sundararajan, S., Prudente, A., Bankston, J. D., King, J. M., Wilson, P., \& Sathivel, S. (2011). Evaluation of green tea extract as a glazing material for shrimp frozen by cryogenic freezing. Journal of Food Science, 76(7) https://doi.org/10.1111/j. 1750-3841.2011.02283.x.

Suvanich, V., Jahncke, M., \& Marshall, D. (2000). Changes in selected chemical quality characteristics of channel catfish frame mince during chill and frozen storage. Journal of Food Science, 65(1), 24-29 https://doi.org/10.1111/j.13652621.2000.tb15950.x.
Tseng, Y.-C., Xiong, Y. L., Webster, C. D., Thompson, K. R., \& Muzinic, L. A. (2002). Quality changes in Australian red claw crayfish, Cherax quadricarinatus, stored at $0{ }^{\circ} \mathrm{C}$. Journal of Applied Aquaculture, 12(4), 53-66 https://doi.org/10. 1300/J028v12n04_05.

Tung, C. L. (2004). Freezing seafood and seafood products; Principles and Applications. Handbook of frozen foods, (Chapter 16).

U.S. Department of Commerce, N. O. A. A., \& Administration (2001). Fisheries of the United States, 2000. Fishery Statistics and Economics Division. Silver Spring: NOAA.

USDA. (2018). Full Report (All Nutrients): 15146, Crustaceans, crayfish, mixed species, wild, cooked, moist heat. https://ndb.nal.usda.gov/ndb/foods/ show $/ 15146$ ?fgcd=\&manu=SIMPLY+BALANCED\&lfacet=\&format=Full\&count= $\& m a x=35 \&$ offset $=0 \&$ sort $=n d b \& o r d e r=a s c \& q l o o k u p=\& d s=\& q t=\& q p=\& q a=$ $\& q n=\& q=\& i n g=$

Venugopal, V., \& Gopakumar, K. (2017). Shellfish: Nutritive value, health benefits, and consumer safety. Comprehensive Reviews in Food Science and Food Safety, 16(6), 1219-1242 https://doi.org/10.1111/1541-4337.12312.

Wanous, M. P., Olson, D. G., \& Kraft, A. A. (1989). Pallet location and freezing rate effects on the oxidation of lipids and myoglobin in commercial fresh pork sausage. Journal of Food Science, 54(3), 549-552 https://doi.org/10.1111/j. 1365-2621.1989.tb04647.x.

\section{Publisher's Note}

Springer Nature remains neutral with regard to jurisdictional claims in published maps and institutional affiliations.
Ready to submit your research? Choose BMC and benefit from:

- fast, convenient online submission

- thorough peer review by experienced researchers in your field

- rapid publication on acceptance

- support for research data, including large and complex data types

- gold Open Access which fosters wider collaboration and increased citations

- maximum visibility for your research: over $100 \mathrm{M}$ website views per year

At BMC, research is always in progress.

Learn more biomedcentral.com/submissions 